\title{
The Cross-Fertilization of Jurisprudence and the Principle of Proportionality \\ Process and Result from a Canadian Perspective
}

*DRAFT*

The Hon. Marie Deschamps, Prof. Maxime St-Hilaire, LL.D, and Pierre Gemson, LL.B1

\section{Introduction}

\section{The Process of Cross-Fertilisation relating to Proportionality}

1.1 The Input: The Role of Foreign sources in Formulating the Oakes Test

1.2 The Output: The Charter and the Oakes Test Abroad

\section{The Result of Cross-Fertilisation relating to Proportionality}

2.1 Proportionality in Canada: s. 1 of the Charter and the Oakes test

2.2 Proportionality in the US: neither central nor absent from the levels of scrutiny doctrine

2.3 Proportionality in Europe: The European Court of Human Rights

2.4 Proportionality in the Americas: the Inter-American Court of Human Rights

\section{Conclusion}

\footnotetext{
1 An initial version of this paper has been presented by the then Honourable Justice Marie Deschamps of the Supreme Court of Canada, at the conference Living Tree Constitutionalism: Democracy, Rule of Law and Human Rights, Canada- México Encounter on Constitutional Interpretation, Legal Theory and Philosophy, UNAM, April 22-23, 2010.
} 
Modern comparative constitutionalism traces back at least to the practice of some states in the post-World War II era of adopting democratic regimes as well as constitutionally entrenched bills of rights. It has since been fueled by the proliferation of international human rights instruments, which has increased with the end of the Cold War. Significant attention was first paid to comparative constitutional structure, but many states have now reached another stage. Indeed, the present focus is on comparative constitutional justice, including comparative constitutional jurisprudence.

As notably witnessed by the works of the Council of Europe and especially those of the Venice Commission in the domain of constitutional justice ${ }^{2}$, the question now is no longer about constitutionalism, including whether rights should be constitutionally protected, as much as it is about constitutional justice: how to effectively implement constitutions. A few years ago, the first World Conference on Constitutional Justice was held, which bore witness to this recent trend in legal practice amongst states ascribing to modern rule of law aspirations. We would like to make this Conference's Final Declaration the starting point of this paper:

\begin{abstract}
The presentations and discussions at the World Conference showed a common concern for the defence of human rights and the rule of law, both on a regional and a global level. Mutual inspiration is also increasingly drawn from the case-law of peer Courts of other countries and even other continents, which gives rise to cross-fertilisation between the Courts on a worldwide scale. While constitutions differ, the basic principles underlying them, in particular the protection of human rights and human dignity and respect for the Constitution and the rule of law, form a common ground. Legal reasoning in respect of the application of these principles in one country can be a source of inspiration in another country, notwithstanding the differences in their Constitutions ${ }^{3}$.
\end{abstract}

One constitutional principle that emerges from, and which is still being forged by, such cross-fertilisation is the principle according to which the limitation of human rights and freedoms must be proportional to states' objectives, that is, the principle of proportionality.

In its larger sense, this principle traces back, at least, to Aristotle. Indeed, we can detect it in Book V (on Justice) of Nicomachean Ethics. In this Book, Aristotle speaks of Justice in terms of proportionality, opposing the geometrical proportionality of political distributive justice to the arithmetical proportionality of legal commutative justice. Regarding the latter, Aristotle explains that, though the lex talionis had the positive impact of introducing a sort of reciprocal proportionality to the realm of justice, it was nonetheless a mere stage of development. Taking an arithmetic approach, it was then possible, thanks to abstract thought, to switch from a sheer

\footnotetext{
${ }^{2}$ http://www.venice.coe.int/site/main/Constitutional_Justice_E.asp

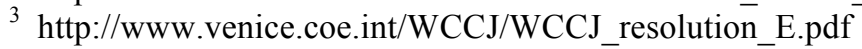


proportional-reciprocal revenge to more positive proportional-reciprocal reparation or restoration. Further development of proportionality would be found in the works of Cicero, Justinian, Thomas Aquinas and Grotius ${ }^{4}$. If we move from reciprocity-based proportionality to necessity-based proportionality, we might think of the common law defense of necessity, which, among other things, allows the Crown to infringe common law rights to the extent to which it is strictly necessary. ${ }^{5}$

What we address here is not proportionality as a broad or abstract principle of legal reasoning. Rather, we speak of proportionality deployed at a particular time in history for particular purposes. The period in history on which we focus is the post-World War II "modern" era, in which the constitutional state of the art was increasingly influenced by the idea that "liberal democratic ordering would not merely define and stabilize the exercise of state power through majoritarian machinery but would give legal priority to equal citizenship and respect for inherent human dignity." 6 The purpose was to reconcile the growing international trend towards rights protection with the fact that rights cannot be absolute but must take into account to some extent the achievement of other legitimate objectives as well as the fact that a state may have to limit certain protected rights in order to promote her rights, or the rights of some in order to safeguard those of others. The requirement that such limitations to right and freedom be proportional to states' objectives was there to recall that accommodating the objectives achieved by limiting rights was not to surrender the right.

Our topic, then, is about proportionality as a principle developed by legal doctrine, constituent authorities, international human rights protection instruments signatories, and the judiciary in order to make sure any limitation of rights remains justifiable. We have to specify that, to the extent that proportionality deals with rights limitation, which refers to a form of substantive review (contrôle matériel), it is generally irrelevant to the question of rights suspension in case of emergency, which tends to be subjected (where subject to review at all) to a more procedural form of review (contrôle formel). Thus the principle of proportionality is, perhaps unfortunately, not a compelling answer to Carl Schmitt ${ }^{7}$.

More specifically, our topic is about both the historical process of jurisprudential cross-fertilisation and its functional result as far as the principle of proportionality is concerned. We speak from a Canadian perspective. The aim here is to be able to distinguish between what is common and what is distinctive about the Canadian approach.

\footnotetext{
4 Eric A, Engle, "The History of the General Principle of Proportionality", (2012) 10 Dartmouth Law Journal 1-11.

5 Albert V. Dicey, An Introduction to the Study of the Law of the Constitution, $1^{\text {st }}$ ed. 1885.

${ }^{6}$ Lorraine E. Weinrib, "The postwar paradigm and American exceptionalism" (2006), Sujit Choudhry ed., The Migration of Constitutional Ideas, $84 \mathrm{ff}$.

7 Political Theology, $1^{\text {st }}$ (german ed.) 1922. We now how the book starts, ie with the famous assertion that:

"Sovereign is he who decides on the exception."
} 


\section{The Process of Cross-Fertilisation relating to Proportionality}

In addition to endowing Canada with the power to amend its constitution independently of the UK Parliament, amendments to the Canadian Constitution proclaimed into law in April 1982 transformed the scope and subject matter of constitutional law. Part I of our 1982 Constitution Act establishes a Charter of Rights and Freedoms and Part II recognizes the collective rights of aboriginal peoples. Hence, in 1982, for the first time in their history, Canadians could claim constitutionally entrenched protection against state interference with legal rights, democratic rights, classical freedoms such as expression, religion and assembly, and rights particular to the Canadian experience such as language rights $^{8}$ and aboriginal rights were constitutionally recognized.

Canada's judiciary, modeled on the British courts where generalist judges uphold the rule of law, were charged with the enhanced role of upholding this new constitutional order. This evolutionary step followed the grain of Canadian constitutionalism to date: since 1867, the courts were tasked with upholding the jurisdictional boundaries between federal and provincial levels of government set by the federative division of powers in the British North America Act. The 1982 reform confirmed power of judicial review and gave it new vigor. To this end the courts were given new tools. Section 52 of the 1982 Constitution Act explicitly declares the Constitution of Canada to be "the supreme law of Canada" and provides that any law inconsistent with the Constitution is "of no force or effect to the extent of the inconsistency." In addition section 24(1) of the Charter permits anyone whose rights have been infringed to apply for "such remedy as [a] court considers appropriate and just in the circumstances." Thus, the grant of remedial jurisdiction vested by the Charter in the courts is explicit and broad - indeed, as our Court stated in its first case interpreting s. 24, "it is difficult to imagine language which could give the court a wider and less fettered discretion." Apart from giving new vigor to judicial review, the 1982 constitutional reform gave it new contents, including the protection of individual rights and freedoms as constitutional rights.

Section 1 of the Charter introduces the guarantee of rights and freedoms and signals that they are not absolute. Charter rights are enjoyed "subject only to such reasonable limits prescribed by law as can be demonstrably justified in a free and democratic society." Thus, at the

\footnotetext{
${ }^{8}$ In 1960, the federal parliament had enacted the Canadian Bill of Rights contrary to which "no law of Canada shall be construed or applied" (s. 2). In practice it had little effect as Courts interpreted it narrowly and were reluctant to declare legislation inapplicable. In 1977 that same parliament enacted the Canadian Human Rights Act in order to "extend the laws in Canada to give effect, within the purview of matters coming within the legislative authority of Parliament, to the principle that all individuals should have an opportunity equal with other individuals to make for themselves the lives that they are able and wish to have and to have their needs accommodated, consistent with their duties and obligations as members of society, without being hindered in or prevented from doing so by discriminatory practices based on race, national or ethnic origin, colour, religion, age, sex, sexual orientation, marital status, family status, disability or conviction for an offence for which a pardon has been granted" (s. 2). This Act had more success in terms of implementation and enforcement. The federated provinces also had enacted such human rights legislation when the 1982 Constitution act came into force. However, all these were statutes which could not have more than quasi-constitutional force, that is, basically, precedence in case of conflict with other legislation.

${ }^{9}$ Mills v. The Queen, [1986] 1 S.C.R. 863, para. 278.
} 
outset, the Charter opens the way to an interpretation that requires weighing rights limitations.

The resulting constitutional order has been described as occupying a unique mid-point between the parliamentary supremacy of the United Kingdom model we had inherited and the judicial supremacy that has grown to characterize the United States Constitution. Such a "uniqueness" thesis perhaps suffers from a certain lack of points of comparison. In the context of rights protection, a unique Canadian approach can be described more precisely, resting on the fact that: 1) the Canadian Charter limitation clause is general rather than rights-specific and, that 2) the justification test the Supreme Court of Canada has developed under s. 1 in the $R$. $v$. Oakes $^{10}$ test combines both a classical deontological approach to rights limitation scrutiny and a rather novel consequentialist one.

Before comparing the proportionality requirement for rights limitations in Canada to other national and supranational jurisprudence from a more systematical standpoint that focuses on current practice, we will begin by taking a more historical perspective and giving a brief account of some available evidence we have that cross-fertilisation between the Supreme Court of Canada and other Courts occurred during in the process of developing Canada's approach to this matter. Cross-fertilisation normally goes both ways. With Canada as the focal point, we will first examine what input it has received from abroad, and then describe how the jurisprudential output of Canadian courts may have influenced practice in other states.

\subsection{The Input: The Role of Foreign sources in Formulating the Oakes Test}

Often relying on a common language and a strong cultural proximity, Canadian counsel litigating early Charter cases and judges adjudicating them tended to look south to the rich constitutional experience of the United States. ${ }^{11}$ For instance, on the question of whether a Sunday shopping ban could be constitutionally valid if it resulted in an unequal economic impact on those whose religious practice mandated a different day of observance in $R$. v. Edwards Books and Art Ltd., ${ }^{12}$ our Court alluded to American jurisprudence upholding such a law in reaching a similar conclusion with respect to an Ontario law.

Yet early on our Court noted that the Charter was a uniquely Canadian document and American precedent was of limited utility. "American jurisprudence" our Court then said, "must be viewed as a tool, not as a master". 13 The cautionary American experience of substantive due process protection of economic interests leading to the controversial Lochner-era practice overturning of legislative measures intended to regulate the economy admittedly has figured prominently in interpreting the Charter's section 7 right not to be deprived of "life, liberty, or security of the person" other than "in accordance with the principles of fundamental justice." While rejecting early on an interpretation of that right which restricted s. 7 to procedural

\footnotetext{
10 [1986] 1 S.C.R. 103.

11 See generally, Gerard V. La Forest, "The Use of American Precedents in Canadian Courts" (1994), 46 Maine Law Review 211.

12 [1986] 2 S.C.R. 713.

13 R. v. Rahey, [1987] 1 S.C.R. 588, 639 (per La Forest J.).
} 
safeguards and holding that s. 7 does possess some substantive content, ${ }^{14}$ our Court has firmly rejected the proposition that 'liberty' includes an economic aspect. Thus, in Reference re ss. 193 and 195.1(1)(C) of the criminal code (Man.), ${ }^{15}$ the challenge to the criminal prohibition on solicitation in public places for the purpose of prostitution was adjudicated on freedom of expression grounds, rejecting arguments based on a purported violation of the right to exercise a profession grounded in economic liberty.

Closer to our topic though, as a 'modern' bill of rights with an explicit limitation clause at $\mathrm{s.1}$ which imported proportionality analysis into Canadian constitutional doctrine, Canada's constitution was more akin to other post-World War II documents such as the German Basic Law and the European Convention on Human Rights. Transatlantic experience could thus be extensively drawn upon.

When Charter challenges to legislation inevitably reached the Supreme Court of Canada, the Court became tasked with developing a method for determining when and how an infringement was justified by s. 1. Section 1 was referenced several times during the first years of Charter litigation but none of those cases required our Court to give it a systematic exposition. Most cases simply concluded that as a threshold matter no section 1 justification was made out. ${ }^{16}$ Still, in Big M. Drug Mart, by stressing the distinction to be made under the Charter between the infringement and the justification questions, Wilson J. presaged the Oakes test. In so doing she also foreshadowed the ultimate rejection of the US Supreme Court's "levels of scrutiny" approach, which accommodates governance needs by varying the scope of the right instead of through a limitation scheme and which, for this reason, remains essentially alien to the principle of proportionality.

In the 1986 case of $R . v$. Oakes the Court was required to squarely address how to apply s. 1 for the first time. The issue in Oakes was the Charter validity of a statutory requirement that persons found in possession of narcotics be required to disprove that they possessed them with the intention to traffic. The statute clearly infringed the Charter's protection of an accused person's right to be presumed innocent at trial. The issue was whether it could be saved by section 1.

The origins of what we now refer to as the Oakes test have received passing scholarly attention. It has been noted that it closely resembles a passage in an earlier case of the United States Supreme Court on acceptable limits to commercial speech. ${ }^{17}$ Oakes itself does not,

${ }_{15}^{14}$ Re B.C. Motor Vehicle Act, [1985] 2 S.C.R. 486.

15 [1990] 1 S.C.R. 1123.

${ }^{16}$ Hunter v. Southam, [1984] 2 S.C.R. 145: A search deemed unreasonable under s. 8 could not be upheld as a reasonable limit to rights through s. 1; Singh v. Minister of Employment and Immigration, [1985] 1 S.C.R. 177: Administrative convenience was not a sufficiently pressing government objective to justify a s. 1 limitation to s. 7 rights to procedural fairness (paras. 69-74).

${ }^{17}$ The resemblance of the Oakes test to United States Supreme Court's test for upholding limitations upon commercial speech in Central Hudson Gas \& Electric Corp. v. Public Service Commission of New York, 477 US 557 (1980) has been noted by scholars and also by the Supreme Court itself in R. v. Ford, [1988] 2 S.C.R. 712. See also Peter Hogg, Constitutional Law of Canada, ' 38.1. 
however, refer explicitly to any external sources in laying down the steps for conducting the proportionality analysis. The Oakes approach also differs considerably from others well established at the time, such as that of the German Constitutional Court in interpreting that country's 1949 Basic Law. We shall see further to what extend it differs from that of the European Court of Human Rights.

Despite the lack of express references thereto, it is apparent that the Oakes test was influenced by foreign experience. Chief Justice Dickson, who authored the unanimous reasons, had the habit of drawing frequently on foreign authorities and academic commentary. His biographers recount that when it became clear, while drafting Oakes, that resort to s. 1 was inevitable, he turned to American and European sources to inform the Canadian approach. ${ }^{18}$ The result is a test comparable in substance and process to those employed in other jurisdictions but with certain distinct Canadian aspects which we will highlight below.

It remains true that the Canadian approach to proportionality bears a striking resemblance to the American test applicable to limitations upon commercial speech, a matter that attracts intermediate scrutiny under the First Amendment, as we shall see. In reviewing the foreign sources one sees that the rational connection aspect of the Oakes test also features notably in the earlier test devised by the US Supreme Court in Central Hudson Gas to determine whether a limit to commercial speech could be constitutionally upheld.

However, on a more general or theoretical level, in the Keegstra case, ${ }^{19}$ the Supreme Court of Canada rejected the 'levels of scrutiny' approach predominant in the United States' constitutional jurisprudence. Instead, the Court drew upon international human rights treaties and the jurisprudence of the then European Commission of Human Rights in determining that the prohibition of racial motivated hate speech could be a valid limitation to the protection given to freedom of expression. It thus reviewed the American case law and studied the American approach, but ultimately decided to reject it in view of other Canadian constitutional imperatives, chiefly "the international commitment to eradicate hate propaganda" to which Canada was a part, and "the special role given equality and multiculturalism in the Canadian constitution."

\subsection{The Output: The Charter and the Oakes Test Abroad}

Although the Charter is not quite yet thirty years old it is nevertheless by now a mature document with its main interpretative contours firmly drawn. We have mentioned that the Canadian Constitution as a whole had been said to occupy a middle ground or third way between what is characterized as the judicial supremacy of the United States Constitution and the parliamentary supremacy of the United Kingdom's. In reality, although perhaps foreign to Anglo-American constitutional culture, such a middle-of-the-path solution, but proceeds from a more continental and international approach resembles approaches taken in Europe and further afield. Our Charter still remains a distinctly Canadian one. Unlike post-war European bills of rights which also contain limitation clauses that are typically attached to individual enumerated

${ }_{18}$ Robert J. Sharpe and Kent Roach, Brian Dickson: A Judge's Journey, p. 334.

19 R. v. Keegstra, [1990] 3 S.C.R. 697. 
rights, it employs a general introductory limitation clause which is arguably applicable to the entire document. Consequently, the Supreme Court of Canada has created a unified framework for justifying rights limitations applicable throughout the Charter: the Oakes test which calls for a proportionality analysis.

One observer from UK has described our Charter as "without doubt the most influential of the modern bills of rights." ${ }^{, 20}$ Apart its impact on the UK, leading examples of Canada's influence can be found in the recent experience of New Zealand, South Africa, and Israel. These cases surely can be largely explained by a common language and legal culture. It has also been argued, however, that beyond such commonalities, Canada's reputation as a tolerant, outward looking and internationalist state and also the universalist tenor of the Charter, consistent with post-war international human rights declarations, set in the Canadian model a tone worthy if emulation. ${ }^{21}$

In the South African case, Canada's longstanding opposition to the apartheid regime dating back to the 1960s made the framers of South Africa's new constitution particularly receptive to Canadian constitutional ideas. ${ }^{22}$ In the case of New Zealand, the early years of the Charter coincided with that country's Labour Party adopting a policy of constitutionally entrenching rights protection. Thus the Canadian experience was closely followed as potentially foreshadowing the effects of such a policy in New Zealand. Additionally, a number of New Zealand constitutional scholars had ties with Canada - having either been graduate students or academic visitors there. Further, one of Canada's leading constitutional scholar, Peter Hogg, is a native New Zealander and he consulted closely with the Labour Party in formulating an ultimately unsuccessful first proposal for a constitutional bill of rights. ${ }^{23}$ Thus is illustrated the contingent and particularized manner in which cross-fertilisation often takes place. While cross-fertilised constitutional drafting is one aspect of this process, cross-fertilised constitutional jurisprudence is another, the latter being our topic here. This brings us to Oakes test's itinerary abroad.

In developing proportionality jurisprudence under the Human Rights Act, British courts have relaxed an otherwise pronounced reluctance to refer to comparative law. Having recognized that "a general international understanding" exists that proportionality is the preferred approach to evaluating whether a rights limitation is permissible, ${ }^{24}$ British courts have drawn on German, American, and Commonwealth sources with Canadian law being "particularly influential."

The UK's experience as a founding member of the ECHR and later as a state that incorporated Convention rights into domestic law illustrates the challenge of combining the international standard of the Strasbourg Court with the exigencies of developing a domestic standard of rights protection. Broadly speaking UK courts have taken a middle road. In defining

\footnotetext{
20 Tom Hickman, "Proportionality: Comparative Law Lessons" (2007), JR 31, 32.

21 Dodek, 321-322.

22 Dodek, 324.

23 Dodek, pp. 312-332.

${ }^{24}$ R. v. Shayler, [2002] UKHL 11, para. 60.
} 
the scope and content of rights the UK has largely followed the Strasbourg jurisprudence. ${ }^{25}$ However, in conducting proportionality analysis the UK has parted ways with Strasbourg. There are practical reasons for this. The supranational jurisprudence of the ECtHR is framed at a level of generality more suited to a supervisory body ensuring minimal adherence to the European Convention across a wide variety of national contexts than to a domestic court seeking to uphold rights in a country with which it is closely familiar. Notably, the "fair balance" standard of the EctHR is more lenient towards rights limitation than the minimal impairment standard of our Court's Oakes jurisprudence.

The differing origins of the EctHR and Oakes approaches to proportionality at least partly explain why the substance of the Oakes test has grown to occupy a central place in the British proportionality jurisprudence. In so doing, Oakes took a circuitous path that offers a particularly curious story of cross-fertilisation. The first British court to consider and apply the Oakes test was the Judicial Committee of the Privy Council sitting on an appeal interpreting the Constitution of Antigua and Barbuda. ${ }^{26}$ The entry point for the Oakes analysis was not, as one might expect, direct reliance on the Canadian authorities - instead, the Privy Council adopted a modified version of the Oakes test developed by the Supreme Court of Zimbabwe in 1996, ${ }^{27}$ itself relying upon Canadian cases. Noteworthy about this original foray into the international proportionality jurisprudence is that the Zimbabwean adoption of Oakes left out the sub-step in the test which, we shall demonstrate later, makes the Canadian approach to proportionality distinctive. We refer to the effects-based proportionality criterion or proportionality in the narrower sense which occurs at the last stage of the Oakes analysis. The truncated version of Oakes (that adopted by the Privy Council in 1999) was subsequently endorsed by Lord Steyn of the House of Lords in an early Human Rights Act case. ${ }^{28}$ In so doing, he relied upon the minimal impairment sub-step, retained from the original Oakes test, in noting that the type of review under the proportionality analysis required by the Human Rights Act would then be "more precise and more sophisticated" than that employed to date under the administrative law test of Wednesbury ${ }^{29}$ unreasonableness, and that "the intensity of review is somewhat greater under the proportionality approach."30

Since then, British Courts have continued to apply proportionality to Human Rights Act cases but "in a relatively ad hoc way" with one commentator bemoaning that "five years since Daly was decided" and with a considerable number of cases decided "the principle of proportionality still remains unelaborated, uncertain and its application unstructured."31 One of the great sources of uncertainty arguably is the issue of what role, if any, the effects-based proportionality analysis in original Oakes test should play in Human Rights Act jurisprudence. ${ }^{32}$

\footnotetext{
Nv. SSHD, [2005] UKHL 31.

${ }^{26}$ de Freitas v. Permanent Secretary of Ministry of Agriculture, Fisheries, Lands and Housing, [1999] 1 A.C. 69.

27 Nyambirai v. National Social Security Authority, [1996] 1 LRC 64.

28 Secretary of State For The Home Department, Ex Parte Daly, R v., [2001] UKHL 26, para. 27.

29 Associated Provincial Picture Houses Ltd, v. Wednesbury Corporation, [1948] 1 KB 223.

30 Daly, para. 27.

31 Hickman, 33.

32 Huang v. Secretary of State for the Home Department, [2007] UKHL 11; Beatson, 203-214.
} 
According to what we have seen above concerning cross-fertilised constitutional drafting and the Canadian Charter's influence on these countries' constitutional human rights architecture, the Oakes test has attracted considerable curial attention of courts in New Zealand and South Africa. Its impact has been most pronounced in New Zealand, where the courts adopted the substance of the Oakes approach ${ }^{33}$ and have kept abreast the evolving interpretation Oakes has been given by Canadian courts, all the while developing a domestic jurisprudence on rights limitation. In South Africa the constitutional text enumerates the criteria to be applied when conducting the proportionality analysis. Nonetheless, Canada's Oakes jurisprudence, along with other foreign cases which the constitutional text also explicitly provides "may" be consulted by South African Courts, has been very influential in establishing a "guiding horizon" for South African cases. ${ }^{34}$ Indeed, on many occasions, the Supreme Court of Canada's reasoning has been relied on as persuasive.

Oakes has also been referred to by the Israeli Supreme Court in interpreting its constitutional bill of rights though less as a model to be followed in these jurisdictions but rather as evidence of comparable practice in similarly minded states. ${ }^{35}$

\section{The Result of Cross-Fertilisation relating to Proportionality}

Changing the focus, let us now turn from diachrony to synchrony, from the history to the system, in other words, from the process to its current results. This entails a brief comparative survey of proportionality in Canada, the US, Europe and the Americas.

\subsection{Proportionality in Canada: s. 1 of the Charter and the Oakes test}

What exactly does the Canadian test for limiting constitutional rights involve? We should emphasize that the test does not merely involve the Oakes analysis, which covers only part of what is required by s. 1 of the Charter. We must distinguish between the steps of the justification test in a broader sense and those of the Oakes test strictly speaking. According to the very wording of s. 1 of the Charter, limitation to rights must be (1) prescribed by law and (2) demonstrably justified in a free and democratic society. The Oakes test corresponds this second step of the broader test of justification s.1 requires.

With respect to the first big step, Le Dain J. dissenting in $R$. v. Therens set out our Court's initial interpretation of the phrase "prescribed by law" in s. 1 of the Charter in the following terms:

The requirement that the limit be prescribed by law is chiefly concerned with the distinction between a limit imposed by law and one that is arbitrary. The limit will be prescribed by law within the meaning of s. 1 if it is expressly provided for by statute or regulation, or results by necessary implication from the terms of a statute or regulation or from its operating

\footnotetext{
${ }^{33}$ Moonen v. Film and Literature Boards of Review, [2000] NZLR 260, Paul Rishworth et al, The New Zealand Bill of Rights (2003), 182-3.

${ }^{34}$ Tania Groppi, "A User-friendly Court: The Influence of the Supreme Court of Canada Decisions Since 1982 on Court Decisions in Other Liberal Democracies", in A Living Tree, 352.

${ }^{35}$ Groppi, pp. 346-7, 355.
} 
requirements. The limit may also result from the application of a common law rule. ${ }^{36}$

The Court later confirmed that it is sufficient that the limit simply result by necessary implication from either the terms or the operating requirements of the "law." ${ }^{37}$ In B.C. Transit, it has said that certain policies adopted by a state actor, where the entity was authorized to enact them and where they are binding rules of general application, may be "law" for the purposes of s. $1 .^{38}$ It thus had the opportunity to reiterated that, for any rights limitation to be considered prescribed by law, it must be sufficiently precise and accessible. ${ }^{39}$

It is for the second big step, relating to what justifies limiting a right in a free and democratic society, that Oakes provides the "test". Dickson C.J. clearly acknowledged in that case that the values of the "free and democratic society" referred to in s. 1 are those which underlie the Charter as a whole. For greater clarity, a forward-looking and non-exhaustive list was provided, which includes human dignity, social justice, pluralism, and the accommodation of societal diversity. ${ }^{40}$ It is such values which were to inform the justification test Dickson C.J. was about to elaborate.

The Oakes test again splits into two big steps, the second of which subdivides into three sub-steps. For a limitation to a Charter right to be justified in a free and democratic society, it must first (2.1) serve a purpose or objective "of sufficient importance to warrant overriding a constitutionally protected right or freedom." (2.2), the limitation must be a reasonable means to pursue the legitimate objective. This means-reasonability sub-test is performed verifying, in succession, (2.2.1) that the means employed in limiting the right are rationally connected to the objective, (2.2.2) that it amounts to nothing more than a minimal impairment of the right, and (2.2.3) that there is a proportional relationship between the positive effects from the pursuit of the objective and the negative effects on the individual resulting from the infringement of a right.

It is the latter three sub-steps taken together that constitute a Canadian variety of the modern legal principle of proportionality in rights limitation. The proportionality relationship referred to in the last sub-step thus has a stricter meaning and function in which, as we will see, lies the distinctiveness of the Canadian approach to proportionality. Regarding the consequentialist/effects-based sub-step (2.2.3), the question before the Court at this stage is "whether the benefits which accrue from the limitation are proportional to its deleterious effects as measured by the values underlying the Charter."

The Canadian approach to proportionality therefore involves threefold analysis: (2.2.1)

\footnotetext{
${ }^{36}$ R. v. Therens, [1985] 1 S.C.R. 613, para. 60.

37 Irwin Toy; B.C.G.E.U. v. British Columbia (Attorney General), [1988] 2 S.C.R. 214; R. v. Swain, [1991] 1 S.C.R. 933 and R. v. Orbanski, 2005 SCC 37, [2005] 2 S.C.R. 3.

${ }^{38}$ Greater Vancouver Transportation Authority v. Canadian Federation of Students C British Columbia Component, [2009] 2 S.C.R. 295, para. 50.

39 Ibidem.

${ }^{40}$ R. v. Oakes, p. 136.

${ }^{41}$ Idem, p. 138.
} 
proportionality in terms of practical rationality; (2.2.2) proportionality regarding the more legal/classical deontological impact; (2.2.3) proportionality concerning the more "realistic" consequentialist impact. These burden of demonstrating proportionality at each stage lies upon the state.

It is noteworthy here, regarding the (2.2.2) minimal impairment sub-step, the Supreme Court of Canada will, in some cases, integrate a measure of deference. This will be done where justified by the context, for example depending upon the nature of the limitation, the sort of activity at stake, the right being infringed, the seriousness of the infringement, and the existence of broadly employed practice for achieving the objective sought. ${ }^{42}$ In Chaoulli, the following factors were also mentioned as calling for greater deference: "the prospective nature of the decision, the impact on public finances, the multiplicity of competing interests, the difficulty of presenting scientific evidence and the limited time available to the state", and the Court further specified: "This list is certainly not exhaustive". ${ }^{43}$ Such an adaptation to context, which our Court also speaks of in terms of the state's "measure of latitude", strongly resembles ECtHR's practice that we will present below and which consist of granting the States a variable "margin of appreciation".

\subsection{Proportionality in the US: neither central to nor absent from the levels of scrutiny doctrine}

Though not as central a concept as it is in most other jurisdictions, proportionality is not unknown to American constitutional law.

The US Bill of Rights formulates its protections in absolute terms and contains no general or specific limitations clauses. Because these rights are nonetheless not absolute, US Courts have been required to develop internal limits to delineate what is inside and outside the scope of protection. What has resulted is a methodology that applies three levels of scrutiny to varying categories of protected interests depending on how "fundamental" the rights at stake are considered to be. These levels are: rational basis, intermediate scrutiny and strict scrutiny.

Instead of testing for overall proportionality, the dominant mode of reasoning applicable to rights limitations under the US Constitution has been described as a balancing process "which concerns the comparison between the burden on the right and the importance of the governmental interest." ${ }^{44}$ The strict scrutiny standard is the most searching level of review US law reserves for infringement of fundamental rights such as freedom from discrimination on the basis of race or protection against content based limitations to free speech. In order to meet it, an offending law must be "necessary to achieve a compelling government purpose", which means that it must represent the least restrictive means available to achieve the objective. ${ }^{45}$

\footnotetext{
42 Montréal (City) v. 2952-1366 Québec Inc., [2005] 3 S.C.R. 141, paras. 92-97; Chaoulli v. Quebec (Attorney General), [2005] 1 S.C.R. 791, paras. 59-98.

43 Para. 95.

44 Iddo Porat \& Moshe Cohen-Elyia, “American Balancing and German Proportionality: The Historical Origins", 8 (Unpublished Paper available at: http://papers.ssrn.com/sol3/papers.cfm?abstract_id=1272763).

45 Chemerinsky, 541.
} 
Notably though, in the decision of the United States Supreme Court on the Second Amendment right to bear arms, Justice Breyer in dissent argued that proportionality was the preferable approach to scrutinizing legislation limiting that right. ${ }^{46}$ He noted that proportionality has been "applied ...in various constitutional contexts, including election law cases, speech cases, and due process cases." $" 47$

\subsection{Proportionality in Europe: The European Court of Human Rights}

Canada's approach to proportionality is distinct in many respects to that developed by the European Court of Human Rights. In part this is due to structural difference between the Charter and the ECHR. The ECHR does not contain a single rights limitation clause. Instead, enumerated rights sometimes also elaborate the limitations to which they may be subject. The relevant provisions are: art. 8.2 (right to respect for private and family life); art. 9.2 (freedom of thought, conscience and religion); art. 10.2 (freedom of expression); art. 11.2 (freedom of assembly and association); Protocol no 1, art. 1.2 (protection of property); Protocol no 4, art. 2.3 (freedom of movement); Protocol no 7, art. 1.2 (procedural safeguards relating to expulsion of aliens).

Like section 1 of the Charter, the rights-specific limitation provisions of the European Convention on Human Rights involve two big steps. For a restriction to right to be justified it must first (1) be in accordance with or prescribed by law, or lawful, and second (2) it must be necessary, in a democratic society, to achieve an objective which is provided for in a limitation clause.

On the first big step, the European Court of Human Rights has said, just as the Supreme Court of Canada did later, that "law" in this sense includes the common law, so that a common law rule may limit a right in a way that conforms the Convention, for to be prescribed by law a limitation must simply be a sufficiently precise and accessible legal norm, no matter what its source. $^{48}$

On the second big step of the analysis, a few points need to be underscored in respect of the permissible objectives for limiting rights and what "free and democratic society" and "necessary" mean to the European Court of Human Rights.

The Strasbourg Court has held that only an objective provided in the limitation clause attaching to a particular right will be recognised by the Court as legitimate. ${ }^{49}$ These objectives vary from one limitation clause to another, but most of them provide that the right of some people may be limited in order to protect that of others.

As for "free and democratic society," we need not be reminded that what represents a necessary means in a non-democratic society might not be considered the same in a democratic

\footnotetext{
46 District of Columbia v. Heller, 128 S. Ct. 2783 (2008).

47 Heller, p. 2851.

48 Golder v. U.-K, 1975; Sunday Times v. U.-K, 1979 ; Silver et al. v. U.-K, 1983; Malone v. U.-K, 1984.

49 De Wilde, Ooms \& Versy v. Belgium, 1970, 1971, 1972; Golder v. U.-K., 1975.
} 
one. Therefore the European Court of Human Rights identified values specific to a democratic society which give the rights limitation justification test its proper shape. These notably are: pluralism, toleration and open mindedness. ${ }^{50}$

On what is "necessary" in a democratic context, the Strasbourg Court specified it needs not mean "indispensable" but can also refer to what is "admissible", "ordinary", "useful", "reasonable" or "desirable" (Handyside; Sunday Times v. The United Kingdom (1979)). However, it still "implies a pressing social need; in particular, the measure employed must be proportionate to the legitimate aim pursued" (Handyside; Gillow v. United Kingdom (1986)). This is how the word "necessary" has become "proportionate" and gave the modern legal principle of proportionality its shape in ECHR jurisprudence.

This raises the question of what "proportional" means to the Strasbourg Court. In reality, just as our Court, the ECtHR adapts its application of this requirement according to : (1) the nature of the objective being sought; (2) the nature of the activities which are "at stake"; (3) whether there exists a common practice of the member States; (4) the nature of the right which is being limited.

Therefore some commentators ${ }^{51}$ refer to two "proportionality" standards: (1) the ordinary one of "fair balance" ${ }^{\text {"52 }}$; and (2) the more relaxed standard of what is not "manifestly unreasonable." ${ }^{53}$ Others even detect a third standard of review to the extent that, in cases where equality has been denied on grounds of nationality, sex, sexual orientation and birth outside marriage, which the Strasbourg Court treats as "suspect", a more searching level of scrutiny requiring "very weighty reasons" has been employed. ${ }^{54}$ In our opinion, it would seem preferable to speak of one single standard which applies differently according to the context. In any event, the "margin of appreciation" of member States will vary accordingly. Indeed, in Sunday Times, recognizing that primary responsibility under the Convention for upholding rights belongs to the states, the Strasbourg Court acknowledged that member States should be afforded a "margin of appreciation" in determining what is "necessary" (ie. "proportionate"). As a result of these varying standards of review, the "margin of appreciation" of member States will vary according to context. Indeed, in Sunday Times, recognizing that primary responsibility under the Convention for upholding rights belongs to the states, the Strasbourg Court acknowledged that member States should be afforded a "margin of appreciation" in determining what is "necessary" (ie. "proportionate"). ${ }^{55}$

\footnotetext{
${ }^{50}$ Handyside v. U.-K., 1976.

${ }_{52}^{51}$ Frédéric Sudre et al., Les grands arrêts de la Cour européenne des droits de l'homme, 4e éd., Paris, Puf, 2007

52 Soering v. United Kingdom, 1989.

${ }^{53}$ Blecic v. Crotia, 2004.

${ }^{54} \mathrm{~J}$. Beatson et al., Human rights: judicial protection in the United Kingdom, London, Sweet and Maxwell Ltd., $2008,86$.

${ }^{55}$ Para. 59.
} 


\subsection{Proportionality in the Americas: the Inter-American Court of Human Rights}

Whereas the American Declaration of the Rights and Duties of Man (April 1948) is actually a few months older than the Universal Declaration of Human Rights and Freedoms (December 1948), the American Convention on Human Rights was adopted not before 1969, ${ }^{56}$ that is, almost 20 years after the European Convention on Human Rights. The enforcement system of the Convention was based on its European equivalent. It is composed of a Commission plus a Court, the Inter-American Court of Human Rights, which is located in San José, Costa Rica. However, unlike recognition of the EctHR's jurisdiction and adherence to the ECHR which are mandatory for all member States of the Council of Europe, both adherence to the American Convention and recognition of the IACtHR's jurisdiction are optional to OAS members.

Canada was a latecomer to the Organization of American States, joining in 1990. Although a full member of the OAS and thus bound by the Declaration for twenty years, Canada has resisted even signing the Convention. The official explanation for Canada's reluctance to adhere to the Convention results from certain differences between the Convention's protections and those typically recognized by Canadian law. For example, concern was expressed that the Convention's protection of the right to life "from the moment of conception" might conflict with Charter rights. Other rights contained in the Convention such as that to equality before the law did not anticipate protections for affirmative action programs which the Charter does. ${ }^{58}$ Nonetheless, the matter has been studied by Canadian lawmakers, and reports of the Senate Committee on Human Rights in 2003 and 2005 recommended Canada ratify the Convention with appropriate reservations and declaration to reflect domestic legal norms. ${ }^{59}$

The ACHR contains several provisions which allow rights limitation. What is noteworthy here about the American Convention is its apparent adoption of both the general (Canadian) and specific (European) limitation clause mechanisms. We say "apparent," because the relevant jurisprudence reveals a different story.

The general rights limitation clauses in the ACHR are found in Article 30 and Article 32.2, which read:

[Article 30] The restrictions that, pursuant to this Convention, may be placed on the enjoyment or exercise of the rights or freedoms recognized herein may not be applied except in accordance with laws enacted for reasons of general interest and in accordance with the purpose for which such restrictions have been established.

[Article 32.2] The rights of each person are limited by the rights of others, by the security of all, and by the just demands of the general welfare, in a democratic society.

\footnotetext{
${ }^{56}$ At the Inter-American Specialized Conference on Human Rights, which took place in San José, Costa Rica, 22 November 1969.

57 Art. 4.1.

58 Statement of Lloyd Axworthy, Minister of Foreign Affairs, to the House of Commons, 1999 quoted in "Enhancing Canada's Role in the OAS: Canadian Adherence to the American Convention on Human Rights", Report of the Standing Senate Committee on Human Rights, May 2003.

59 Canadian Adherence to the American Convention on Human Rights: It is Time to Proceed, Report of the Standing Senate Committee on Human Rights, May 2005.
} 
Although these provisions deal with objectives, that is, with ends which may justify some limitation to right, as far as means are concerned they do not provide any criterion, such as necessity or proportionality, regarding the extent to which it is permitted to limit rights in the pursuit of a legitimate objective. The only mention of means is in Article 30 which requires a limitation to be "in accordance with laws".

As for the more European specific rights limitation clauses of the American Convention, they are in art. 12.3 (freedom of conscience and religion; art. 13.2 (freedom of thought); art. 15 (right of assembly); art. 16.2 (freedom of association); art. 21.1 (right to property) ; art. 22.3 (freedom of movement and residence); art. 23.2 (right to Participate in Government). All of these but 21.1 and 23.2 read as being capable of triggering the application of the principle of proportionality, for they provide for a "necessity" requirement similar to that of the ECHR.

The Inter-American system gets closer to the ECtHR, and farther from Canada, when we learn from the IACtHR's advisory opinion on The Expression "Laws" in Article 30 of the American Convention on Human Rights that:

Article 30 cannot be regarded as a kind of general authorization to establish new restrictions to the rights protected by the Convention, additional to those permitted under the rules governing each one of these [rights]. The purpose of the article, on the contrary, is to impose an additional requirement to legitimize individually authorized restrictions. ${ }^{60}$

The American Convention generally requires rights limitations to be in accordance with, or prescribed by, law. The leading case on this is that very same advisory opinion on The Expression "Laws" in Article 30 of the American Convention on Human Rights, which confirms that "the criteria of Article 30 are applicable to all those situations where the word "laws" or comparable expressions are used in the Convention in referring to the restrictions that the Convention itself authorizes with respect to each of the protected rights." ${ }^{\prime 61}$ The Court took into account "the fact that the legal regimes of the States Parties to the Convention each have their source in a different tradition," more specifically, that "[s]ome States Parties can be said to form part of the Common Law system while others follow the Civil Law system," and it referred here to the ECtHR's decision in Sunday Times. ${ }^{62}$ However, after also referring to the ICJ's principle of legality, it has given a definition of law which might arguably exclude common law rules and about which one surely can wonder: has the Inter-American Court of Human Rights here, on this specific requirement of legality, somehow switched from a formal requirement to a substantive one ? Indeed, after saying that "the concepts of legality and legitimacy coincide," unanimously concludes:

That the word "laws" in Article 30 of the Convention means a general legal norm tied to the general welfare, passed by democratically elected legislative bodies established by the Constitution, and formulated according to the procedures set forth by the constitutions of the

\footnotetext{
${ }^{60}$ The Expression "Laws" in Article 30 of the American Convention on Human Rights, Advisory Opinion OC-6/86 of May 9, 1986. Series A No. 6, par. 17.

${ }^{61}$ Par. 17.

${ }^{62}$ Par. 20.

${ }^{63}$ Par. 37.
} 
States Parties for that purpose. ${ }^{64}$

We also learn from this case that the Court interprets the "applied in accordance with the purpose..." requirement of Article 30 more like a "rational connection" criterion ${ }^{65}$ which resembles that in Oakes, thus providing for an additional criterion than those existing in the specific limitation clauses. The possibility of a rational connection test is confirmed by the Kimmel v. Argentina case. ${ }^{66}$

Although the limitation clauses of the American Convention do not, contrary to the ECHR, always restrict limitation to those "necessary in a democratic society", the Inter-American Court's advisory opinion on Compulsory membership in an association prescribed by law for the practice of journalism made it clear that such a requirement was established by Article 29, which provides that "[n]o provision of this Convention shall be interpreted as precluding other rights or guarantees that are inherent in the human personality or derived from representative democracy as a form of government." The Court clearly held that this interpretive article applies not only to rights protection clauses, but also to rights limitation clauses, thereby introducing the principle of interpretive limitations to the limitation of rights. ${ }^{67}$ The Court also read-in a "necessity" requirement for any provision of the Convention that can possibly be construed as specifically permitting the limitation of a right. The Yatama $v$. Nicaragua case involved, among other rights, political rights, dealing with the "right to participate in government." ${ }^{, 68}$ Whereas Article 23.2 permits the States by law to "regulate the exercise" of political rights "on the basis of age, nationality, residence, language, education, civil and mental capacity, or sentencing by a competent court in criminal proceedings," the Court, in Yatama, subjected such a limitation to the justification test it developed in its advisory opinion on Compulsory membership in an association prescribed by law for the practice of journalism as well as in freedom of expression and freedom of movement and residence cases, so that the test became one of general application. ${ }^{69}$ This was confirmed in Castañeda-Gutman v. Mexico ${ }^{70}$, and is also well illustrated in the even more recent case Tristán-Donoso v. Panama. ${ }^{71}$ This case partly dealt with the right to privacy. Although Article 11.2 simply says that "[n]o one may be the object of arbitrary or abusive interference with his private life, his family, his home, or his correspondence, or of unlawful attacks on his honour or reputation," the Court stated that any non-arbitrary or non-abusive interference or any lawful limitation of this right "must be established by law, pursue a legitimate purpose and be necessary in a democratic society.,"72 This trend was recently continued in Escher et al. v. Brazil. ${ }^{73}$

\footnotetext{
64 Par. 38.

65 Par. 18.

${ }^{66}$ Kimmel v. Argentina, May 2, 2008, Series C No. 177, par. 58, 68-71.

67 Compulsory membership in an association prescribed by law for the practice of journalism (Arts. 13 and 29 American Convention on Human Rights), Advisory Opinion OC-5/85, November 13, 2005, Series A No. 5 , par 44

${ }^{68}$ Yatama v. Nicaragua, June 23, 2005, Series C No. 127.

69 Par. 206.

${ }^{70}$ Par. 185.

71 Tristán-Donoso v. Panama, Judgment of January 27, 2009. Series C No. 193.

72 Par. 56.

73 Escher et al. v. Brazil, July 6, 2009, Series C No. 200, par. 116, 129.
} 
It seems safe to say that for a state to limit any ACHR right, such a limitation must be specifically provided for in the Convention, so that invoking a general limitation clause alone will not suffice, and be "necessary" in a democratic society, even though necessity is not required by in the specific limitation clause.

In respect of the principle of proportionality, it appears that the aforementioned advisory opinion on Compulsory membership in an association prescribed by law for the practice of journalism introduced it into the Inter-American Human Rights System. And it did so in the same manner as its European equivalent had already done, even referring to the ECtHR's decision in Sunday Times. ${ }^{74}$

Indeed, in the 2004 Herrera-Ulloa v. Costa Rica case, the Court referred to its advisory opinion Compulsory membership in an association prescribed by law for the practice of journalism. It said that "the restriction must be proportionate to the legitimate interest that justifies," more precisely that it "must be limited to what is strictly necessary to achieve that objective." "75 This "strict necessity" criterion was reiterated about two months later, in Ricardo Canese v. Paraguay. ${ }^{76}$ Nearly four years later, in May 2008, it was maintained in Kimmel v. Argentina, where the Court, not only used the very same words, but also spoke of necessity in terms of "strict proportionality" ${ }^{77}$ However, a closer look at the decision reveals that the Court conceived of such a "strict proportionality" merely in terms of not rendering the right "nugatory" ${ }^{78}$ In August 2008, the Court in Castañeda-Gutman v. Mexico, spoke instead in terms of a measure "that least restricts the protected right." 79 This criterion seems to have been confirmed in a very recent case, Usón Ramírez v. Venezuela, which notably returns to and find support in the Court's advisory opinion in Compulsory membership in an association prescribed by law for the practice of journalism. ${ }^{80}$

What is striking is that, whereas the case law of the IACtHR bases itself on the ECtHR's Sunday Times case of 1979 in order to apply a "strict proportionality" principle which it also presents as a "least restrictive" criterion, the fact is that Sunday Times, does not contain this criterion. In sum, somewhat paradoxically the IACtHR's jurisprudence is much closer to Oakes' minimal impairment standard than to ECtHR's "fair balance".

\footnotetext{
74 Par. 46.

75 Herrera-Ulloa v. Costa Rica, July 2, 2004, Series C No. 107, para. 123, 133.

76 Ricardo Canese v. Paraguay, August 31, 2004, Series C No. 111, par. 95.

77 Para. 54, 56.

78 Para. 58, 84.

79 Para. 186, 194ss.

80 Usón Ramírez v. Venezuela, November 20, 2009, Series C No. 207.
} 
Constitutional interpretation, even today, prompts comments about judicial activism. Contemporary critics of judicial activism might be reminded, though, that the tenor of debate in its previous form is outdated. There is an almost worldwide consensus on the principle of constitutional justice. In Canada, for instance, popular support for the Charter and the actions of the courts in striking down legislation remained quite high even at the height of the judicial activism debate, whatever heat and light the judicial activism debate may have generated. ${ }^{81}$ In reality, the worldwide debate has been overtaken by another one. The question now is: what best practices should judges should follow? Broadly speaking one answer has been found in the process of jurisprudential cross-fertilisation that can be traced throughout Europe, New Zealand, South Africa and in the Americas: as far as human rights and freedoms are concerned, limits to these rights should be justified according to the principle of proportionality.

Having conducted a succinct comparative analysis of the proportionality principle, what is striking is that the remarkable convergence in the results reveals more on cross-fertilisation than the study of its process. Indeed, the similarities are prominent, notably those relating to what it means for a rights limitation to be prescribed by law, how the values of a free and democratic society are articulated, the requirement that a limitation to a right be rationally connected to the objective it pursues, the requirement any limitation minimally impair a right, and the practice of adjusting the review vary according to some common contextual criteria. Thus the inevitable conclusion is that cross-fertilisation is largely an unconscious or unspoken phenomenon.

With respect to what differs between jurisdictions, we note that the ECtHR's standard of review remains less stringent overall than the Supreme Court of Canada's and the IACtHR's. We would also recall that, amongst the systems here compared, only the Canadian one comprises a general limitation mechanism which vests the courts with the responsibility for determining what represents a legitimate objective with regard to rights limitation. It is difficult to assess fully what this means in practice because we are in lack of a survey of the various objectives which so far have been recognized to be legitimate by Canadian courts. But it is the third difference on which we want to focus in concluding this paper: the distinctive consequentialist, effects-based proportionality analysis that Oakes framework requires at its final step.

In Dagenais v. Canadian Broadcasting Corp., ${ }^{82}$ Lamer C.J. reiterated the importance of measuring effects-based proportionality within the Oakes analysis. What resulted is a reinvigoration of this very last stage of the test according to which a court must weight up both

81 Peter Hogg, “The Charter Revolution: Is It Undemocratic?” (2001/2002), 12 Constitutional Forum 1, 1 ff.

82 [1994] 3 S.C.R. 835. 
the salutary and deleterious effects of the rights limitation to see if they are proportionate to each other. In a recent article, the former President of the Israeli Supreme Court, Aharon Barak, took issue with professor Peter Hogg's longstanding argument that if a limitation passes the minimal impairment stage of Oakes, there is little work left to be done at this last stage of the proportionality analysis. Barak's view was that the last stage of Oakes remained important and achieved the task of determining whether the achieving the objective of the limitation "is commensurate with the deleterious effect upon the human right... [which] requires placing colliding values and interests side by side and balancing them according to their weight." Barak might have added that Hogg approached the matter from the perspective typical in law and which focuses the review in sheer legal terms, upon the scope of infringement to the right. Hogg did not take into account the novel consequentialist considerations of the effects-based proportionality step of the Oakes analysis. Our Court recently reiterated Barak's view and reaffirmed its longstanding position that each step of Oakes serves a distinct and important purpose. $^{83}$

It seems to us this distinctive jurisprudential feature is in line with contemporary philosophical thought, which tends to recognize the legitimacy of both deontological and consequentialist perspectives and stresses the need to combine them. ${ }^{84}$

${ }^{83}$ Alberta v. Hutterian Brethren of Wilson Colony, 2009 SCC 37, [2009] 2 S.C.R. 567, para. 72-103.

${ }^{84}$ Daniel M. Weinstock, Profession éthicien, Montréal, Presses de l'Université de Montréal, 2006, pp. 17-22. 